\title{
MARITIME ENVIRONMENTAL PERFORMANCE INDICES: USEFUL TOOLS FOR EVALUATING TRANSPORT SUPPLIER ENVIRONMENTAL PERFORMANCE?
}

\author{
ANASTASIA CHRISTODOULOU \\ Department of Business Administration, School of Business, Economics and Law, \\ University of Gothenburg, Sweden
}

\begin{abstract}
The growing concern of shippers about the carbon footprint of their supply chains led to the development of various environmental indices that enable the measurement of transport supplier's environmental performance. This paper focuses on the environmental performance indices that were developed for the shipping industry that enable the measurement and comparison of environmental performance of individual vessels. Two environmental indices for shipping, the Environmental Ship Index (ESI) and the Clean Shipping Index (CSI), were analyzed for this paper: we highlight their particular features and give some evidence of their practical implementation. The scope of this paper involves investigating the usefulness of these indices for shippers and freight suppliers' decision-making and identifying their effectiveness at improving the environmental performance of shipping services. The environmental differentiated port fees offered by Port Metro Vancouver in Canada and the Port of Gothenburg in Sweden, on the basis of the vessels' ESI and CSI scoring were investigated. The fact that, in both ports, the number of vessels that have an ESI score or a CSI Class is constantly growing, suggests that eco-labelling initiatives and the use of environmental performance indices are becoming more and more popular in the shipping industry. Apart from the shipping companies that might choose a port that rewards 'cleaner' vessels, the shippers themselves may require employed vessels to have such an ecolabel to demonstrate their commitment to sustainable transport. Given the growing concern of shippers about the environmental performance of their supply chains, this paper suggests that these indices are useful tools for the evaluation and measurement of transport supplier environmental performance; they could be used by shippers and freight suppliers for their decision-making about transport mode choices.
\end{abstract}

Keywords: carbon footprint, supply chain, sustainable procurement, environmental performance, environmental performance indices, air pollution, maritime transport, shipping, emissions.

\section{INTRODUCTION}

The purchasing process for freight transport services is dominated by various factors that influence the transport mode choice for shippers and freight suppliers. Besides the most common factor categories (cost, transit time, reliability) that have impacted the purchasing process for transport services, environmental considerations have been ranked high in recent transport mode choice literature [1]-[3]. The growing concern of shippers about the environmental performance and the carbon footprint of their supply chains has led to the development of various environmental indicators and indices, that enable the evaluation and measurement of the transport supplier's environmental performance. Although the main principles and characteristics of environmental performance indices are similar among industrial sectors, special indices have been developed for the evaluation of environmental performance of different segments, in order to include specific factors and parameters, and measure their environmental output.

This paper focuses on the environmental performance indices that have been developed for the shipping industry, and that enable the measurement and comparison of the environmental performance of individual vessels. The fact that more than $90 \%$ of the global 
trade volume is transferred by maritime transportation indicates the importance of assessing the environmental performance of maritime services for the establishment of sustainable supply chains [4]. Two environmental indices for shipping were analyzed in this paper, highlighting their particular features and differences, and giving some evidence of their practical implementation. The scope of this paper was to investigate the usefulness of these indices for shipper and freight supplier decision-making, and to identify their effectiveness at improving the environmental performance of shipping services.

\section{LITERATURE ON SUSTAINABLE TRANSPORTATION PROCUREMENT AND ENVIRONMENTAL PERFORMANCE INDICES FOR MARITIME SERVICES}

Many authors have mentioned the factors that have impact on transport mode choice, as the topic is quite complex and the interactions of various parameters need to be taken into consideration [1], [5]-[8]. These various factors have been categorized in different ways, as the purchasing of literature and different trends on the relevant importance of these factors have been raised over the years. The roles of environmental and sustainability considerations in the purchasing process of transport services have been highlighted most recently in scientific articles [9], [10].

Maritime transport is by far the most environmentally-friendly and energy-efficient mode, due to the economies of scale that imply there are both low energy consumption and air emissions per unit of transport work [11]-[13]. Despite this environmental advantage, during the last decades there was a growing concern about sustainability issues in the maritime industry [14], [15]. The main reason is the fact that greenhouse gas (GHG) emissions from shipping are forecast to increase significantly in the coming years, in line with increased demand for shipping services [4], [16], while emissions from international maritime transport modes have not been included in any international agreement for combating climate change, such as the Kyoto Protocol or the Paris Agreement [17], [18]. A wide range of initiatives were adopted for the abatement of maritime air emissions, which were undertaken by different actors: from inter-governmental organizations to national, regional, public institutions and private associations [19], [20].

'Eco-labelling' is a quite popular informative initiative targeting shipping-related air emissions, and this includes various environmental indices that enable the measurement and comparison of the environmental performance of individual vessels. Many ports worldwide provide discounts (known as environmentally differentiated port dues) to 'cleaner' vessels that have a high score by these indices [20], and they could also be useful tools for shippers and freight suppliers in their efforts to include sustainability aspects in their maritime transport decisions [21].

According to Svensson and Andersson [22], an Environmental Performance Index for Shipping is "an index of aggregated environmental data or indicators for the purpose of communicating a ship's or shipping company's environmental performance". The main principles of environmental performance indices for shipping include [22]:

1. The use of data on the operational performance of the vessels.

2. The aggregation of this data into scores.

3. The expression of this aggregated data in a final index.

4. The communication of this index in the form of a certificate, a label, a rating or a ranking.

On the basis of these principles and the database of initiatives targeting the maritime air emissions developed by Christodoulou et al. [20], there were 12 environmental performance indices for shipping that can be identified (Table 1). 
Table 1: Environmental Performance Indices for shipping.

\begin{tabular}{|c|c|c|}
\hline Indices & Organization & Short description \\
\hline $\begin{array}{l}\text { Energy } \\
\text { Efficiency } \\
\text { Operational } \\
\text { Indicator (EEOI) }\end{array}$ & $\begin{array}{l}\text { IMO } \\
\text { (International } \\
\text { Maritime } \\
\text { Organisation) }\end{array}$ & $\begin{array}{l}\text { A monitoring tool for managing ship and fleet } \\
\text { efficiency performance over time. The EEOI } \\
\text { enables operators to measure the fuel } \\
\text { efficiency of a ship in operation and to gauge } \\
\text { the effect of any changes in operation. }\end{array}$ \\
\hline $\begin{array}{l}\text { Environmental } \\
\text { Ship Index (ESI) }\end{array}$ & $\begin{array}{l}\text { IAPH } \\
\text { (International } \\
\text { Association of } \\
\text { Ports and } \\
\text { Harbours) } \\
\end{array}$ & $\begin{array}{l}\text { The ESI evaluates the amount of nitrogen } \\
\left.\text { oxide }(\mathrm{NO})_{\mathrm{X}}\right) \text { and sulphur oxide }\left(\mathrm{SO}_{\mathrm{X}}\right) \text { emitted } \\
\text { by a ship; it includes a reporting scheme for } \\
\text { the ship's greenhouse gas emission. }\end{array}$ \\
\hline $\begin{array}{l}\text { Rightship } \\
\text { (Existing Vessel } \\
\text { Design Index } \\
\text { (EVDI)) }\end{array}$ & Rightship & $\begin{array}{l}\text { The EVDI measures } \mathrm{CO}_{2} \text { emitted per tonne- } \\
\text { miles, based on ship design. The GHG } \\
\text { Emissions Rating is a rating scheme of ships' } \\
\mathrm{CO}_{2} \text { emissions from A to G (most to least } \\
\text { efficient), based on EVDI scores. }\end{array}$ \\
\hline $\begin{array}{l}\text { Clean Cargo } \\
\text { Working Group } \\
(\mathrm{CCWG})\end{array}$ & $\begin{array}{l}\text { BSR (Business } \\
\text { for Social } \\
\text { Responsibility) }\end{array}$ & $\begin{array}{l}\text { The CCWG is a business-to-business } \\
\text { leadership initiative involving major brands, } \\
\text { cargo carriers, and freight forwarders } \\
\text { dedicated to reducing the environmental } \\
\text { impacts of global goods transportation and } \\
\text { promoting responsible shipping. PMT and } \\
\text { EPS are environmental performance } \\
\text { scorecards for ocean container ships. The data } \\
\text { includes: } \mathrm{CO}_{2}, \mathrm{SO}_{\mathrm{X}}, \mathrm{NO}_{\mathrm{X}} \text {, } \\
\text { waste/water/chemical management, EMS and } \\
\text { transparency. Each category is scored based } \\
\text { on set performance thresholds (indexed } \\
\text { average for } \mathrm{CO}_{2} \text { ), included in a final } \\
\text { scorecard. }\end{array}$ \\
\hline $\begin{array}{l}\text { Environmental } \\
\text { Awareness }\end{array}$ & $\begin{array}{l}\text { Nippon Kaiji } \\
\text { Kyokai (Class } \\
\text { NK) }\end{array}$ & $\begin{array}{l}\text { Environmental Awareness (EA) is an } \\
\text { additional class notation for Class NK ships. } \\
\text { The requirements for EA are set by an } \\
\text { "environmental guideline" that consists of } \\
\text { minimum requirements and additional } \\
\text { requirements. While the minimum } \\
\text { requirements consist of compliance with } \\
\text { MARPOL regulations, the additional ones are } \\
\text { for ships that take more advanced } \\
\text { environmental measures. These ships obtain } \\
\text { additional marks to their notation. }\end{array}$ \\
\hline
\end{tabular}


Table 1: Continued.

\begin{tabular}{|c|c|c|}
\hline Indices & Organization & Short description \\
\hline Green Award & $\begin{array}{l}\text { Green Award } \\
\text { Foundation }\end{array}$ & $\begin{array}{l}\text { Green Award certifies ships that are extra } \\
\text { clean and extra safe. The Green Award } \\
\text { Requirements address issues related to } \\
\text { quality, safety, the environment and technical } \\
\text { areas related to the ship and its manager's } \\
\text { office. The most recent update of the Green } \\
\text { Award requirements covers, for example, } \\
\text { Monitoring of Ship Exhaust Emissions and } \\
\text { the Marpol NOX emission limits. }\end{array}$ \\
\hline $\begin{array}{l}\text { RAL-UZ } 141 / \\
\text { RAL-UZ } 110\end{array}$ & $\begin{array}{l}\text { German Federal } \\
\text { Environmental } \\
\text { Agency }\end{array}$ & $\begin{array}{l}\text { The Blue Angel eco-label aims to implement } \\
\text { as many environmental innovations as } \\
\text { possible for reducing releases into the marine } \\
\text { environment during the planning phase, for a } \\
\text { sea-going ship. Requirements range from } \\
\text { emergency towing system installation, to } \\
\text { measures for air pollutant reduction and fuel } \\
\text { tank protection (double hull). Also included } \\
\text { are demanding requirements for onboard } \\
\text { waste and wastewater treatment. }\end{array}$ \\
\hline Triple-E & $\begin{array}{l}\text { Det Norske } \\
\text { Veritas and } \\
\text { Germanischer } \\
\text { Lloyd (DNV GL) }\end{array}$ & $\begin{array}{l}\text { Triple-E provides the shipowners and } \\
\text { operators with a self-assessment tool for the } \\
\text { ships' environmental performance. The } \\
\text { assessment ends up with an environmental } \\
\text { rating of ships from } 4 \text { to } 1 \text { ( } 1 \text { is highest). It } \\
\text { consists of the following key elements: } \\
\text { environmental management; energy efficient } \\
\text { operation and design; and verifiable } \\
\text { monitoring, measurement and documentation. }\end{array}$ \\
\hline $\begin{array}{l}\text { Clean Shipping } \\
\text { Index }\end{array}$ & $\begin{array}{l}\text { Clean Shipping } \\
\text { Index (CSI) }\end{array}$ & $\begin{array}{l}\text { The CSI is an independent labelling system of } \\
\text { the environmental performance of ships and } \\
\text { shipping companies. The basis of the Clean } \\
\text { Shipping Index is a questionnaire covering the } \\
\text { environmental performance of ships. The } \\
\text { parameters are: } \mathrm{SO}_{x}, \mathrm{NO}_{\mathrm{X}}, \mathrm{CO}_{2} \text {, chemicals, } \\
\text { water and waste, and particulate matter. }\end{array}$ \\
\hline $\begin{array}{l}\text { Good } \\
\text { Environmental } \\
\text { Choice }\end{array}$ & $\begin{array}{l}\text { Swedish Society } \\
\text { for Nature } \\
\text { Conservation } \\
\text { (SSNC) }\end{array}$ & $\begin{array}{l}\text { To get the Good Environmental Choice } \\
\text { ecolabel for transport, there are requirements } \\
\text { to do with energy efficiency and emission } \\
\text { levels of } \mathrm{NO}_{\mathrm{X}} / \mathrm{SO}_{\mathrm{X}} \text {. }\end{array}$ \\
\hline
\end{tabular}


Table 1: Continued.

\begin{tabular}{|l|l|l|}
\hline Indices & Organization & Short description \\
\hline $\begin{array}{l}\text { Enviro and } \\
\text { Enviro }+\end{array}$ & $\begin{array}{l}\text { American Bureau } \\
\text { of Shipping } \\
\text { (ABS) }\end{array}$ & $\begin{array}{l}\text { Additional notation aimed at compliance with } \\
\text { adopted international regulations (regardless } \\
\text { of ratification). In order to obtain the } \\
\text { notations, compliance with MARPOL Annex } \\
\text { I, II, IV, V and VI are a prerequisite. Enviro + } \\
\text { is more stringent toward design } \\
\text { characteristics, management systems, sea } \\
\text { discharges and air emissions. }\end{array}$ \\
\hline Green Marine & $\begin{array}{l}\text { Green Marine } \\
\text { Management } \\
\text { Corporation }\end{array}$ & $\begin{array}{l}\text { Voluntary environmental certification } \\
\text { program for the U.S. and Canadian marine } \\
\text { industry. The initiative addresses key } \\
\text { environmental issues through 12 performance } \\
\text { indicators. To receive certification, } \\
\text { participants must benchmark their annual } \\
\text { environmental performance. They need to } \\
\text { have their results verified by an accredited } \\
\text { external verifier and agree to publication. }\end{array}$ \\
\hline
\end{tabular}

\section{METHODOLOGY}

Two environmental indices are analyzed in this paper, the Environmental Ship Index (ESI) and the Clean Shipping Index (CSI). The selection of these indices was based on their overall use by port authorities for the estimation of differentiated environmental port dues and the accurate aggregation of operational performance data into scores. Fig. 1 presents the various indices that form the basis for the provision of economic incentives by ports.

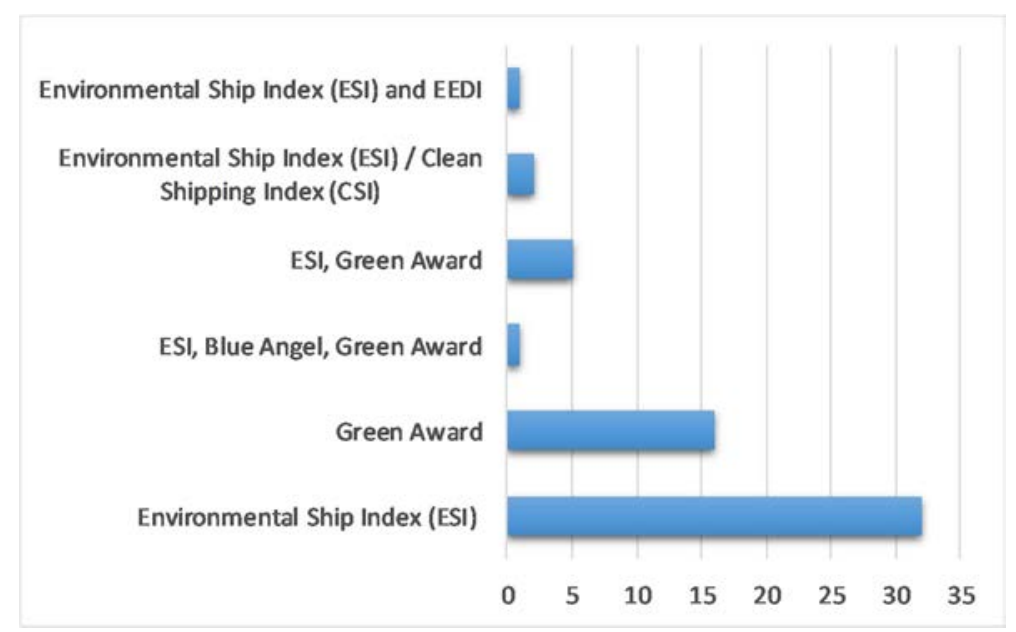

Figure 1: Environmental performance indices that form the basis for the provision of environmentally differentiated port dues. (Source: Own elaboration based on the database developed by Christodoulou et al. [20].) 
The ESI is the most commonly used index for the provision of economic incentives by ports, which is an expected outcome, as this index was developed by the International Association of Ports and Harbours (IAPH): it represents an index created by ports themselves. Another popular index is the Green Award, which is not included in our study, due to its complex scoring system that includes different requirements for different types of vessels and distinct criteria that need to be fulfilled in order for the vessels to be certified.

In order to answer the first research question: whether these environmental performance indices for maritime services are useful for shippers and freight suppliers' decisions, we made an attempt to evaluate these indices on the basis of the existing theoretical framework. The evaluation scheme for the environmental performance indices for shipping developed by Svensson and Andersson [22], in addition to the best practices for eco-labelling, mentioned by Poulsen et al. [21], were used as underlying guidelines for the evaluation of the maritime environmental indices. The ESI and CSI were evaluated on the basis of:

1. their comprehension,

2. the quantification and aggregation of the data (transparency),

3. the third-party verification (credibility),

4. their holistic approach

5. their frequency of use for the provision of economic incentives (legitimacy) (Fig. 2).

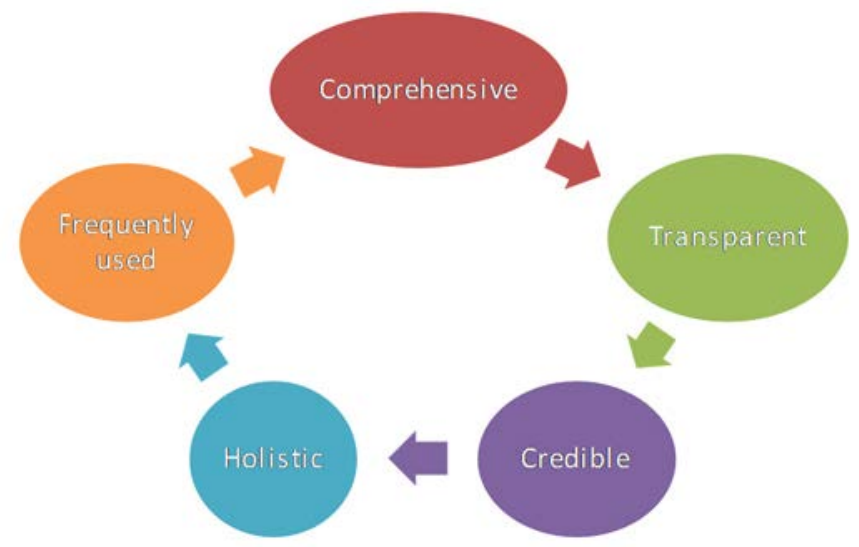

Figure 2: Evaluation criteria for the ESI and CSI. (Source: Own elaboration, based on Svensson and Andersson [22] and Poulsen et al. [21].)

Our second research question: were these indices effective for the improvement of the environmental performance of shipping services? We attempted a thorough interpretation of their practical implementation. The environmental differentiated port fees offered by the Port Metro Vancouver and the Port of Gothenburg, on the basis of the vessels' ESI and CSI scoring, were analyzed to shed light on the wider adoption of these indices by shipping companies and port authorities. These ports were chosen as they are two leading port authorities that acknowledge sustainability as one of their core values, an integral part of the ports' operations as a whole, and as they use both indices as their basis for assessment of port fee discounts for cleaner vessels. We used data from the ports' websites and sustainability reports, in order to form a concrete view of their sustainability practices. 


\section{FINDINGS}

\subsection{ESI - CSI evaluation}

Comprehension: According to our findings, both ESI and CSI are voluntary systems to label vessels' environmental performance that can be applied to all types of sea-going ships. They only cover ships that perform over and above current international legislation by the International Maritime Organisation. Their databases had 7889 vessels for the ESI and 2400 vessels for the CSI. ESI includes sulphur oxides $\left(\mathrm{SO}_{\mathrm{X}}\right)$, nitrogen oxides $\left(\mathrm{NO}_{\mathrm{X}}\right)$ and carbon dioxide $\left(\mathrm{CO}_{2}\right)$ emissions. Also, CSI gives additional points for chemicals, water and waste.

Credibility: Under the CSI, the third-party verification is voluntary and requires that a carrier apply and pay for it, although it is required in order to obtain a 'green rank' for vessels and for carriers. A "Certificate of Verification" is issued for a vessel, then uploaded into the database by the verifier, if the verification shows full compliance. On the condition that performance does not decrease, this certificate is valid for three years. Accredited verification companies are mainly classification societies: DNV GL, Bureau Veritas, Class NK, Lloyds Register, Korean Register, Rina Services, Verifavia, MRVControl, Dromon Bureau of Shipping and Emicert. ESI data are based on the ship-owner's self-assessment, although a port authority may be granted the right to audit data that are, have been or will be included in the port's incentive program.

Transparency: The aggregation of the data differs among the two indices. The ESI formula is built up of different parts for $\mathrm{NO}_{\mathrm{X}}, \mathrm{SO}_{\mathrm{X}}$ and $\mathrm{CO}_{2}$; additionally, a bonus is awarded for the presence of an On-shore Power Supply (OPS) installation. The installation of OPS can result in significant emissions reductions, as vessels can turn off their auxiliary engines and use shore-side electricity for their activities while at berth. The ESI Score ranges from 0 for a ship that just meets the environmental performance regulations that are in force, to 100 for a ship that emits no $\mathrm{SO}_{\mathrm{X}}$ and no $\mathrm{NO}_{\mathrm{X}}$, and reports or monitors data to establish its energy efficiency. The weighing factor of the $\mathrm{NO}_{\mathrm{X}}$ sub-points within the ESI Score is twice that of the $\mathrm{SO}_{\mathrm{X}}$ sub-points. This reflects the fact that the average environmental damage to air from $\mathrm{NO}_{\mathrm{X}}$ in ship emissions is approximately twice the damage obtained from $\mathrm{SO}_{\mathrm{X}}$.

The basis of the CSI is a digital questionnaire covering a vessel's environmental performance. Final scores for vessels are based on the outcome of the questionnaire. Under the CSI, a total of 150 points can be obtained; 30 points for each of the five different parameters: $\mathrm{SO}_{\mathrm{X}}, \mathrm{NO}_{\mathrm{X}}, \mathrm{CO}_{2}$, chemicals, and water and waste. The final score results in a designation of CSI Class $1-5$, according to the scheme in Table 2:

Table 2: CSI classification. (Source: CSI [21].)

\begin{tabular}{|l|c|}
\hline CSI Class 5: 125 & 150 points \\
\hline CSI Class 4: 100 & 124 points \\
\hline CSI Class 3: 75 & 99 points \\
\hline CSI Class 2: 38 & 74 points \\
\hline CSI Class 1: 0 & 37 points \\
\hline
\end{tabular}

Holistic approach: The CSI system consists of a network of members built up from a broad range of maritime stakeholders: shippers, freight forwarders, shipping companies, ports, clean technology suppliers; in contrast to the ESI, that is restricted to shipping companies and ports. The fact that many large shippers (like Volvo, Volkswagen, H\&M, Philips, Stora 
Table 3: Ports that provide discounts to cleaner vessels on the basis of the ESI or CSI. (Source: Own elaboration, based on ESI and CSI [23], [24].)

\begin{tabular}{|c|c|c|c|}
\hline \multicolumn{2}{|r|}{ ESI } & \multicolumn{2}{|c|}{ CSI } \\
\hline Sweden & Gothenburg & Sweden & $\begin{array}{l}\text { Gothenburg, } \\
\text { Gävle, } \\
\text { Brofjorden, } \\
\text { PetroPort }\end{array}$ \\
\hline Canada & Prince Rupert, Vancouver & Canada & $\begin{array}{l}\text { Vancouver, } \\
\text { Prince } \\
\text { Rupert }\end{array}$ \\
\hline Germany & $\begin{array}{l}\text { Hamburg, Bremen, SEEHAFEN KIEL } \\
\text { GmbH \& Co. KG, Brunsbüttel Ports GmbH, } \\
\text { Rostock, Niedersachsen Ports, DNVGL } \\
\text { ECO Insight }\end{array}$ & & \\
\hline Belgium & Antwerp, Zeebrugge, Ghent Port Company & & \\
\hline Italy & Autorità Portuale di Civitavecchia & & \\
\hline France & $\begin{array}{l}\text { Le Havre, Ports of Paris, Atlantic Port La } \\
\text { Rochelle, Grand Port Maritime de Marseille, } \\
\text { Grand Port Maritime De La Réunion }\end{array}$ & & \\
\hline Israel & Ashdod & & \\
\hline USA & $\begin{array}{l}\text { Los Angeles, The Port Authority of New } \\
\text { York and New Jersey }\end{array}$ & & \\
\hline Netherlands & $\begin{array}{l}\text { Amsterdam, Groningen Seaports, Green } \\
\text { Award Foundation, Tata Steel IJmuiden } \\
\text { Terminals, Zeeland Seaports }\end{array}$ & & \\
\hline Norway & $\begin{array}{l}\text { Oslo, Kristiansand, Stavanger, Alesund, } \\
\text { Bergen, Flåm and Gudvangen, Florø } \\
\text { (Alden), Fredrikstad and Sarpsborg, } \\
\text { Karmsund, Drammen, Trondheim }\end{array}$ & & \\
\hline Portugal & Port Authority of Setúbal and Sesimbra & & \\
\hline Oman & Sohar & & \\
\hline South Korea & Busan Port Authority & & \\
\hline Japan & Tokyo, Yokohama & & \\
\hline $\begin{array}{l}\text { New } \\
\text { Zealand }\end{array}$ & Port Nelson Limited & & \\
\hline Panama & Panama Canal Authority & & \\
\hline UK & Port of London Authority & & \\
\hline Argentina & Buenos Aires & & \\
\hline Finland & Port of Helsinki Ltd & & \\
\hline Australia & Botany, Kembla & & \\
\hline
\end{tabular}

Enso and Tetra Laval) are involved in this system verifies their commitment to sustainable transport services. Legitimacy (frequency of use for the provision of economic incentives): The provision of economic incentives at ports on the basis of these indices is quite popular. High-scoring vessels with an ESI or CSI certificate are offered environmentally differentiated port discounts for their good environmental performance. The discounts vary widely among 
port authorities (from 5-50\% of the port fees) and can be initiated either by governmental or regional policies, or by the port authorities themselves. There are few ports that offer discounts based on both indices (Table 3).

4.2 Environmentally differentiated port dues offered by the Port Metro Vancouver and the Port of Gothenburg

Both the Port Metro Vancouver and the Port of Gothenburg offer environmentally differentiated port dues to vessels that have either high ESI or CSI scores. In 2007, the Port Metro Vancouver introduced its "EcoAction Program" that included EcoAction Award Levels, which give discounts on the basis of vessel environmental performance [25]. Vessels with an ESI score above 40 or a CSI Class 5 receive a Gold discount (47\%) on their port fees, while the discount is Silver (35\%) for vessels with an ESI score between 31 and 39, or CSI Class 4. Finally, the Bronze (23\%) discount is offered to those vessels with an ESI score between 20 and 30, or a CSI Class 3. The program has been quite successful over the years, with the number of qualifying vessel calls increasing significantly since 2011 (Table 4) [26].

Table 4: Number of qualifying vessels calling the Port Metro Vancouver (2011-2017). (Source: Port Emissions Inventory Report [26].)

\begin{tabular}{|l|c|c|c|c|c|c|c|}
\hline Year & 2011 & 2012 & 2013 & 2014 & 2015 & 2016 & 2017 \\
\hline Number of qualifying vessels & 332 & 440 & 521 & 520 & 416 & 612 & 759 \\
\hline
\end{tabular}

Coming to the Port of Gothenburg, vessels that have a score of at least 30 ESI points or at least CSI Class 4 receive a $10 \%$ discount on the port fees. According to a Gothenburg sustainability report [27], in 2015, they had $29 \%$ of vessels calling at the Port of Gothenburg that received an environmental discount.

The fact that, in both ports, the number of vessels that have an ESI score or a CSI Class is constantly getting larger, suggests that eco-labelling initiatives and the use of environmental performance indices is becoming more popular in the shipping industry. The higher participation in these eco-ranking schemes is potentially driven by the increasing requirements for shippers to have lower emissions, and the consequent use of such an ecolabel to demonstrate their commitment to sustainable transport. It is worthwhile to mention that, from 2015 till 2017, the number of registered ships that have an ESI score of 50 or higher has increased fourfold [28].

According to our findings, the provision of economic incentives to have "cleaner" vessels has had an influence on giving a competitive advantage at ports. In the case of Canadian ports, for example, the port of Prince Rupert that is located close to the Port Metro Vancouver on the Canadian west coast, introduced in 2013 the "Green Wave Program", which is quite similar to the previously mentioned Ecoaction Program [29]. The program offers discounts on port fees on the basis of environmental performance indices, among which are the ESI and CSI. The obvious reason for the adoption of the program is that the port did not want to lose traffic from ships that could make use of these incentives in a neighbor port. We can see a similar situation on the Canadian east coast, where both the Port of Montreal and the Port of Sept Iles offer 10\% rebates on the basis of the Green Award Program.

Apart from the shipping companies that might choose a port that rewards vessels with an ESI score or a CSI Class in order to benefit from the port discounts, the shippers themselves may require employed vessels to have such an ecolabel, to demonstrate their commitment to sustainable transport. Shippers can use the ESI and CSI to select more fuel-efficient vessels 
during their procurement process for vessel capacity. In this case, shipping companies with eco-ranked vessels could have additional economic benefits, as shippers are more likely to select these vessels during their procurement process, resulting in a higher utilization capacity of certain ecolabeled carriers.

\section{CONCLUDING DISCUSSION}

This paper focuses on the potential use of environmental indices to improve the environmental performance of maritime transport services. Two environmental indices are analyzed in this paper: the ESI and the CSI, selected due to their overall use by port authorities for the provision of environmentally differentiated port dues and the accurate aggregation of operational performance data into scores.

According to our findings, both indices are comprehensible and transparent. The credibility of the CSI is quite larger, when compared to the ESI, due to the requirement for third party verification that is performed by various classification societies. The CSI also has a more holistic approach, consisting of a network of members built up from a broad range of maritime stakeholders: shippers, freight forwarders, shipping companies, ports, clean technology suppliers; in contrast to the ESI, that is restricted to shipping companies and ports. The ESI is the most commonly used index for the provision of economic incentives by ports, which is an expected outcome, as this index was developed by the IAPH and is formed by the ports themselves in their efforts to improve their own environmental performance.

In order to examine whether these indices are effective at improving the environmental performance of shipping services, we attempted a thorough interpretation of their practical implementation. We analyzed the environmentally differentiated port fees offered by the ports of Metro Vancouver and Gothenburg, on the basis of vessels' ESI and CSI scoring, in this paper and shed light on the wider adoption of these indices by shipping companies and port authorities. The fact that, in both ports, the number of vessels that have an ESI score or a CSI Class is constantly getting larger, suggests that eco-labelling initiatives and the use of environmental performance indices are becoming ever more popular in the shipping industry.

Given the growing concern of shippers about the environmental performance of their supply chains, this paper does suggest that these indices are useful tools for the evaluation and measurement of the transport supplier's environmental performance, and that they could be employed by shippers and freight suppliers for making their transport mode choice decisions. The use of the ESI and CSI enables shippers to select more fuel-efficient vessels, in their procurement process for vessel capacity. Shipping companies with eco-ranked vessels can gain additional economic benefits, as shippers are more likely to select these vessels in their procurement processes, resulting in higher utilization capacity of the carriers. For the shipping industry as a whole, the eco-labelling initiatives like the ESI and the CSI help improve the standards of environmental performance in shipping, and can lead to reduced external costs for maritime services. Regional or international regulations targeting the abatement of maritime air emissions could also be enhanced by the wide use of environmental performance indices.

Our research design does not allow us to generalize the findings on the use of the environmental performance indices by port authorities, due to the limited number of port authorities that have been included in the study. The data sources from two port authorities cannot be considered as representative of port environmental sustainability practices in general, as the specific port authorities are located in Northern Europe and North America, where high sustainability requirements in sea freight transport are applied and a strong commitment in sustainable port operations is demonstrated. The results might be different for small- or medium-sized ports, or other geographical regions of the world; however, the 
attitudes of leading port authorities in environmental sustainability towards the use of environmental performance indices for the provision of economic incentives are worthwhile to investigate, due to the valuable practical input that they can offer, in relation to the novelty of environmentally differentiated dues in ports.

\section{ACKNOWLEDGEMENT}

This study was supported by the Swedish Maritime Competence Centre Lighthouse.

\section{REFERENCES}

[1] Cullinane, K. \& Toy, N., Identifying influential attributes in freight route/mode choice decisions: a content analysis. Transportation Research Part E: Logistics and Transportation Review, 36(1), pp. 41-53, 2000.

[2] Lammgård, C. \& Andersson, D., Environmental considerations and trade-offs in purchasing of transportation services. Research in Transportation Business \& Management, 10, pp. 45-52, 2014.

[3] Christodoulou, A., Demand aspects of RoRo shipping services - The shippers' perspective. Proceedings of the 27th IPSERA Conference, pp. 278-287, 2018.

[4] Smith, T.W.P. et al., Third IMO GHG Study, International Maritime Organization (IMO) London, 2014.

[5] Flodén, J., Bärthel, F. \& Sorkina, E., Transport buyers choice of transport service - A literature review of empirical results. Research in Transportation Business \& Management, 23, pp. 35-45, 2017.

[6] Hedvall, K., Dubois, A. \& Lind, F., Variety in freight transport service procurement approaches. Transportation Research Procedia, 25, pp. 806-823, 2017.

[7] Loetveit, P.E. \& Gray, R., The transport selection criteria of Norwegian exporters. International Journal of Physical Distribution \& Logistics Management, 28(2), pp. 108-120, 1998.

[8] Meixell, M.J. \& Norbis, M., A review of the transportation mode choice and carrier selection literature. The International Journal of Logistics Management, 19(2), pp. 183-211, 2008.

[9] Evangelista, P., Environmental sustainability practices in the transport and logistics service industry: An exploratory case study investigation. Research in Transportation Business \& Management, 12, pp. 63-72, 2014.

[10] Large, R.O., Kramer, N. \& Hartmann, R.K., Procurement of logistics services and sustainable development in Europe: Fields of activity and empirical results. Journal of Purchasing \& Supply Management, 19(3), pp. 122-133, 2013.

[11] Cullinane, K.P.B. \& Khanna, M., Economies of scale in large container ships. Journal of Transport Economics and Policy, 33(2), pp. 185-208, 1999.

[12] López-Navarro, M.Á., Environmental factors and intermodal freight transportation: Analysis of the decision bases in the case of Spanish motorways of the sea. Sustainability, 6(3), pp. 15-44, 2014.

[13] Medda, F. \& Trujillo, L., Short-sea shipping: An analysis of its determinants. Maritime Policy \& Management, 37(3), 285-303, 2010.

[14] Giziakis, C. \& Christodoulou, A., Climate change and marine industry. International Association of Maritime Economists Conference, Copenhagen, 2009.

[15] Giziakis, C. \& Christodoulou, A., Environmental awareness and practice concerning maritime air emissions: the case of the Greek shipping industry. Maritime Policy and Management, 39(3), pp. 353-368, 2012. 
[16] UNCTAD, Review of Maritime Transport 2015, UNCTAD: Geneva, Switzerland, 2015.

[17] Kyoto Protocol. United Nations Framework Convention on Climate Change (UNFCCC), Kyoto, 1997.

[18] Romera, B.M., The Paris Agreement and the Regulation of International Bunker Fuels. Review of European Commpunity \& International Environmental Law, 25(2), pp. 215227.

[19] Goulielmos, A., Giziakis, C. \& Christodoulou, A., A future regulatory framework for $\mathrm{CO}_{2}$ emissions of shipping in the Mediterranean area. International Journal of EuroMediterranean Studies, 4(1), pp. 39-60, 2011.

[20] Christodoulou, A., Gonzalez-Aregall, M., Linde, T., Vierth, I. \& Cullinane, K., Targeting the reduction of shipping emissions to air: A global review and taxonomy of policies, incentives and measures. Maritime Business Review, 2019.

[21] Poulsen, R.T., Hermann, R.R. \& Smink, C.K., Do eco-rating schemes improve the environmental performance of ships? Marine Policy, 87, pp. 94-103, 2018.

[22] Svensson, E. \& Andersson, K., Inventory and Evaluation of Environmental Performance Indices for Shipping, Chalmers University of Technology, 2012.

[23] Clean Shipping Index, Methodology and Reporting Guidelines, CSI: Gothenburg, Sweden, 2018.

[24] Environmental Ship Index, www.environmentalshipindex.org/Public/PortIPs. Accessed on: 1 Mar. 2019.

[25] Port Metro Vancouver, EcoAction Program, 2018.

[26] Port of Vancouver, 2017 port emissions inventory report. Port of Vancouver, 2018.

[27] Gothenburg Port Authority, Sustainable port. Sustainability Report of Gothenburg Port Authority, 2016.

[28] Becqué, R., Fung, F. \& Zhu, Z., Incentive Schemes for Promoting Green Shipping. Natural Resources Defense Council (NRDC), 2018.

[29] Port of Prince Rupert. Green Wave Program, 2018. 